\title{
症例報告 VI
}

\section{粘膜下層の浸潤部では脈管侵襲のみが認められた 大腸 $\mathrm{II}_{\mathrm{c}}$ 型 $\mathrm{sm}$ 癌の 1 例}

\author{
順天堂大学消化器内科（“現社会保険中央総合病院大腸肞門病センター） \\ 碓 井 芳 樹 ${ }^{*}$ 近藤 健 司 \\ 管原病院 \\ 佐 藤 智 則 佐 藤 光 重 \\ 埼玉医科大学第 2 外科 \\ 浜田節 雄 \\ 順天堂大学第 1 病理 \\ 北村 成大
}

\begin{abstract}
癌が粘膜に限局している状態で粘膜下層に脈管侵襲を認めた大腸 II c 型癌を経験した．患者は61歳男性で， 6 年前に胃癌で手術を受け，2年半前に大腸多発癌で手術を受けていた。術後経過観察目的の大腸内視鏡検 查で，下行結腸に宿凹性病変を認め，他に多発の大腸ポリープも認めた．俩山性病変は生検で腺癌であった ため，既往の手術により盲管となった左側横行結腸と下行結腸を切除した．検索の結果，下行結腸の陥凹性 病変は大きさ $4 \times 6 \mathrm{~mm}$ 大のI c 型癌で，癌は粘膜に限局していたが，粘膜下層の静脈に脈管侵襲をきたし ていた，その他， $2 \mathrm{~mm}$ のII b 型の de novo の m癌を含む多発早期癌を認めた．胃癌では粘膜下浸潤の一 形式として脈管侵襲によるむのが報告されているが，大腸において現在まで，このような浸潤形式の報告は ないので報告した.
\end{abstract}

索引用語 : 大腸早期癌, 大腸 II c 型癌, 脈管侵襲

\section{I.はじめに}

異時性多発大腸癌で, しかも異時性他臓器重複癌の患 者に認められた II c 型大腸早期癌において，癌が粘膜に 限局していたにもかかわらず，粘膜下層の静脈に癌浸潤 を認めた。このような報告は，大腸においては支献上な いので報告する．

\section{II. 症例}

患者: 61歳, 男性.

主訴 : 経過観察目的.

既往䄳：1983年胃癌で胃亜全摘. 1985年硬膜下血腫で 手術. 1987年 4 月腹部の激痛のため, 緊急手術となり, 上行結腸に進行癌を認め, 右半結腸切除, 回腸 $\$$ 状結腸 側側吻合術施行. 残存の横行結腸の口側は妄端とした. 切除標本の検索の結果, 進行癌 (a2) と早期癌 $(\mathrm{sm})$ を
認めた。

家族歴：特記事項なし.

現病歴：1989年 9 月に術後経過観察目的で大腸内視鏡 検查を行い，多発の有茥性ポリープと下行結腸の陥凹性 病変を認めた. 同病変の生検で腺癌の病理診断を得たた め，手術目的で入院とした，尚，生検では粘膜笳板以下 への浸潤に認めなかった。

大腸内視鏡検查（生検 1 力月後）：下行結腸に胃の川 を思わせる様な陥凹性病変（図 1) を認め，内視鏡的ポ リープ摘除は技術的に困難と判断された。

入院時現症 : 頭部, 腹部に手術創をみる他, 特記事項 なし.

入院時検査所見：血算, 生化学検查に異常なし. CA 19-9 10U/ml と正常.

盲管となった左側横行結腸と下行結腸を切除した. $\mathrm{H}_{0}, \mathrm{P}_{0}, \mathrm{~S}_{0}, \mathrm{M}(-), \mathrm{N}(-)$ であった. 


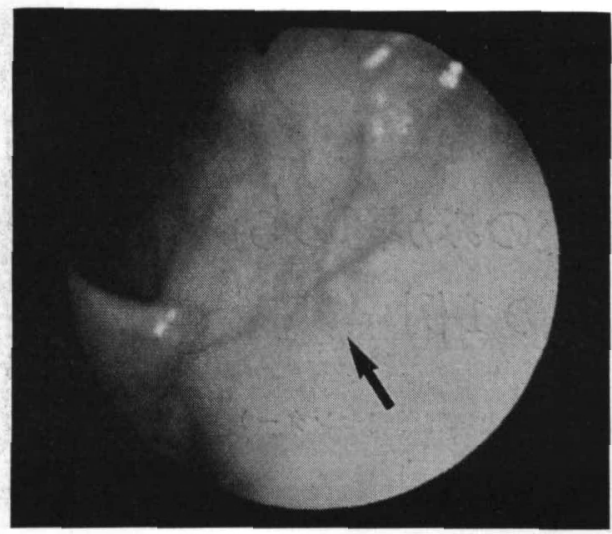

図 1 下行結腸に認められた胃の I c 型早期癌を 思わせる陥凹性病変 (矢印部) の内視鏡像.

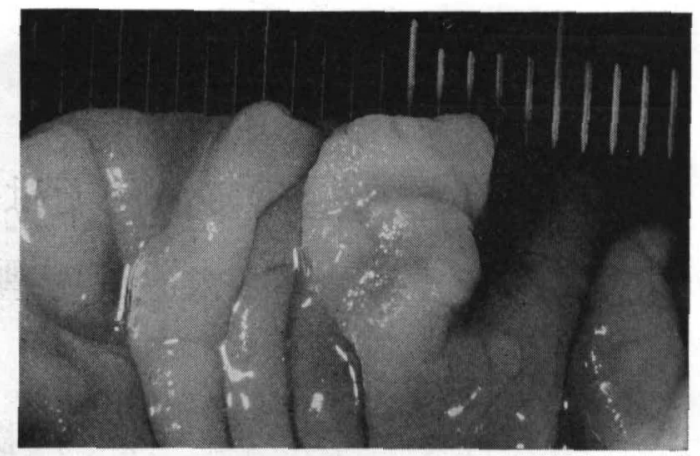

図 2 切除固定標本における図 1 に示した病変 の肉眼所見. $4 \times 6 \mathrm{~mm}$ の不整な陥凹を 認める。

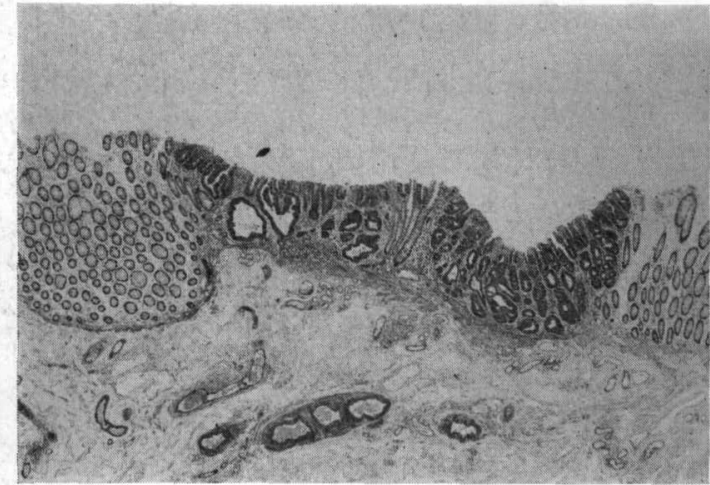

図 3 腺腫の介在のない腺癌を粘膜に認め, 癌部は 明かに陷四している。 ( HE 染色 $\times 20)$

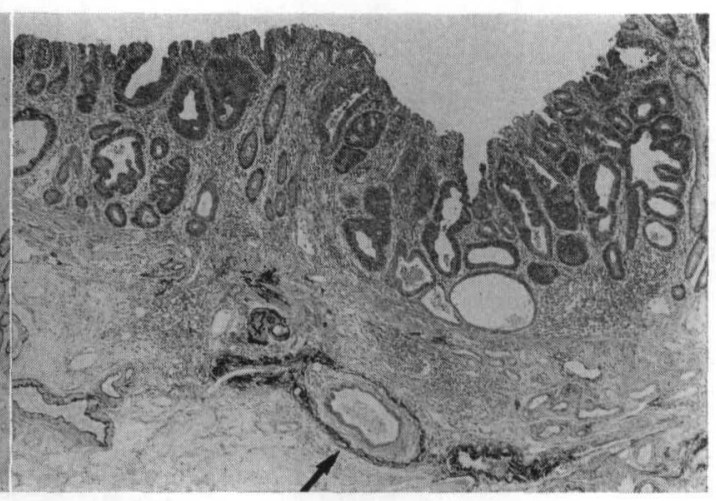

図 4 粘膜下層の静脈に癌侵襲 (矢印部) を認める. $(\mathrm{EvG}$ 染色 $\times 40)$



図 5 図 4 の拡大像. ( $E v G$ 染色 $\times 200)$

切除標本の病理検查 : 図 1 で示した病変の固定写真を 図 2 に示した。 $4 \times 6 \mathrm{~mm}$ の不整形をした陷凹性病変で あった。切り出しは腸管に垂直に病変を挟むように行 い. 連続切片を作製した. 図 3 は, 同病変の組織像の写 真である. 癌は, 粘膜に限局しており, 癌部は周囲の正

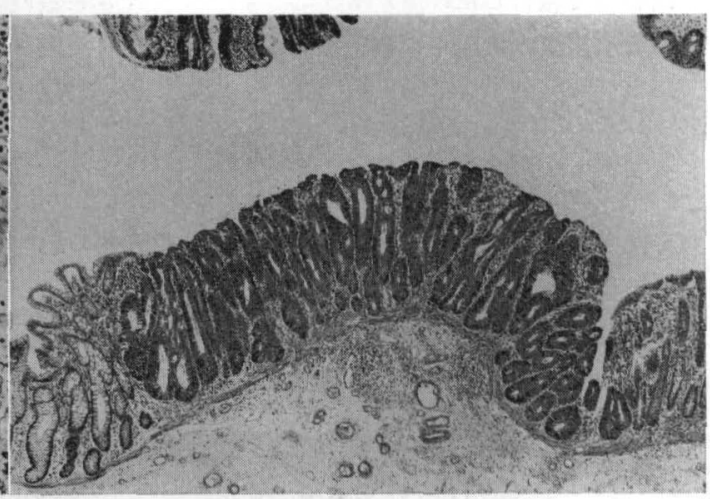

図 6 腺腫の介在のない腺癌を粘膜に認め, 癌部は flat である. ( $\mathrm{HE}$ 染色 $\times 40)$

常粘膜に比べ，明かに陥凹している.腺腫の介在のない， de novo 発生の II c 型癌であり, 深達度は, この組織像 からは $\mathrm{m}$ 癌と診断されるが, 別の切片で, 粘膜笳板直下 の粘膜下層の脈管に癌腺管を認めた. エラスチカワンギ ーソン $(\mathrm{EvG})$ 染色の結果, この脈管は静脈であること 
が判明した（図 4，5）.連続切片の検索の結果，癌は粘 膜に限局しており，静脈にみられた癌腺管は静脈内に留 まっており，粘膜の癌組織との連続性はなく，静脈侵熟 と診断した，その他に， $2 \mathrm{~mm}$ のIb 型 de novo の $\mathrm{m}$ 癌 (図 6)，8 $\mathrm{mm}$ の I p 型 $\mathrm{sm}$ 癌 (II c 型癌の約 15 $\mathrm{cm}$ 口側に存在, $\mathrm{EvG}$ 染色で $\mathrm{v}(-)$ であった)，13mm の I p 型 $\mathrm{m}$ 癌, $10 \mathrm{~mm}$ の $\mathrm{I}$ 型m癌を認めた.

\section{III. 考 察}

近年, 平坦・陷四型早期癌が多く発見され治療される ようになり11，大腸の粘膜癌は転移を有する報告がない ことから，ポリペクトミーや局所切除で完治とみなされ ている.しかし, 本例のように, 癌の主坐が粘膜に限局 している状態で粘膜下層の脈管侵襲陽性例があることよ り，粘膜癌に沶いて脈管因子から遌隔転移を来す可能性 が示唆されているとも言える. 大倉らは22，大腸の粘膜 下組織浸潤㾔での脈管侵襲の検索で，陮凹性病変では大 きさ $10 \mathrm{~mm}$ を超えるとほぼ全例に脈管侵襲が 認められ ると述べて扔り， Ic 型の $\mathrm{sm}$ 癌の場合，脈管侵襲を 認めることは，めずらしいことではないが，本例の様に 癌が粘膜に限局している，いわゆる $\mathrm{m}$ 癌の症例で粘膜下 層に脈管侵襲を認めたという報告はない．

胃癌では，篠原ら 3 が粘膜下組織への浸潤様式を 4 種 類に分けて報告しており，その中の脈管侵襲型に本例が 当てはまると思われる。

本例は大腸癌でも胃癌と同様な脈管侵襲による浸洞形
式があるといえる貴重な1例であり， m癌でむ脈管を介 しての転移があることを示しているものである. 今後, このような症例がどの程度の頻度で存在するかは，症例 の蓄積によって明かとなるであ万うが，平坦・楩凹型の m癌でストリップバイオプシーで治療された場合む，綮 重なフォローアップを忠ってはならないと思われる。

\section{IV. 結 語}

大腸 I c 型癌において，癌が粘膜に限局していたが， 粘膜下層の静脈に癌浸潤を認めた例をはじめて報告し た.

稿を終るにあたり，ご指導，ご校閲下さった社会保險 中央総合病院大腸肛閒病七ンタ一岩垂純一部長, 秋田赤 十字病院外科 工藤進英部長に深謝します。

（本例は, 第 50 回日本消化器内視鏡学会関東地方会で 報告した)。

\section{文献}

1）工藤進英, 牛山 信, 三浦宏二ほ加：平坦・陥凹 型大腸早期癌一 $\mathrm{sm}$ 浸潤形式，発育進展を中心に 一. 消外 $14: 277-295 ， 1991$

2）大倉康男, 中村恭一，伴 慎一ほ加：大腸微小痛 の組織発生とその癌の発育進展. 消外 $13: 407$ 418,1990

3）簙原直宏,望月 真：胃癌の粘膜下組織への初期 浸潤様式. 胃と腸 25:1469-1475，1990 


\title{
A Case of Type IIc Cancer Having Submucosal Venous Invasion without Direct Submucosal Invasion
}

\author{
Y. Usui* and K. Kondo \\ Department of Gastroenterology, Juntendo University, Tokyo \\ *Department of Colo-proctology, Social Insurance Central Hospital, Tokyo \\ T. Satou and M. Satou \\ Kagohara Hospital \\ S. Hamada \\ Second Department of Surgery, Saitama Medical School, Saitama \\ S. Kitamura \\ First Department of Pathology, Juntendo University, Tokyo
}

\begin{abstract}
We experienced II c type de novo colon cancer which did not invade the submucosa directly, but had venous invasion in the submucosa. We found this case to be unique. The patient is a 61-year-old man who was operated on for gastric cancer six years ago and operated on for multiple colon cancers two years ago. For the purpose of following up after the operation, we examined him by colonoscopy. The depressed lesion which was proved carcinoma by biopsy, and multiple polyps were found in the colon. The left side transverse colon and descending colon which became blind loop by the past operation were resected. By studying the resected specimen, $4 \times 6 \mathrm{~mm}$ II $\mathrm{c}$ type cancer which did not invade the submucosa directly, but had venous invasion in the submucosa and multiple early cancers including II b type de novo mucosal cancer were found. It seems to be the same type as the infiltration in the submucosa by the vessel invasion with gastric cancer.
\end{abstract}

